Working Paper/Document de travail 2013-24

\title{
Is There a Quality Bias in the Canadian CPI? Evidence from Micro Data
}

by Oleksiy Kryvtsov 
Bank of Canada Working Paper 2013-24

July 2013

\title{
Is There a Quality Bias in the Canadian CPI? Evidence from Micro Data
}

\author{
by \\ Oleksiy Kryvtsov \\ Canadian Economic Analysis Department \\ Bank of Canada \\ Ottawa, Ontario, Canada K1A 0G9 \\ okryvtsov@bankofcanada.ca
}

Bank of Canada working papers are theoretical or empirical works-in-progress on subjects in economics and finance. The views expressed in this paper are those of the author.

No responsibility for them should be attributed to the Bank of Canada or Statistics Canada. 


\section{Acknowledgements}

In conducting the work reported in this paper, confidential access was obtained to Statistics Canada's Consumer Price Research Database, thanks to John Baldwin, Richard Evans and Danny Leung. I am especially grateful to Catherine Michaud, Marc Prud'homme and Ning Huang for their invaluable support and guidance in using the data. I thank Bob Amano, Jean Boivin, Gino Cateau, Allan Crawford, Erwin Diewert, John Greenlees, Kim Huynh, Kam Yu, seminar participants at the Bank of Canada, Statistics Canada and the 2011 Price Measurement Advisory Committee meeting for useful comments and suggestions. Claudiu Motoc provided superb research assistance. I thank Glen Keenleyside for excellent editorial assistance. All remaining errors are my own. 


\begin{abstract}
Rising consumer prices may reflect shifts by consumers to new higher-priced products, mostly for durable and semi-durable goods. I apply Bils' (2009) methodology to newly available Canadian consumer price data for non-shelter goods and services to estimate how price increases can be divided between quality growth and price inflation. I find that less than one-third of observed price increases during model changeovers should be attributed to quality growth. This implies overall price inflation close to inflation measured by the official index. I conclude that, according to Bils' methodology, the quality bias is not an important source of potential mismeasurement of CPI inflation in Canada.
\end{abstract}

JEL classification: E31, M11, O47

Bank classification: Inflation and prices; Potential output

\title{
Résumé
}

La hausse des prix à la consommation s'explique peut-être par le déplacement des achats des ménages vers de nouveaux produits - surtout durables et semi-durables - assortis de prix plus élevés. L’auteur applique la méthodologie de Bils (2009) à de nouvelles données canadiennes sur les prix des biens et services non liés au logement afin d'estimer la part des augmentations imputable à l'amélioration de la qualité plutôt qu'à l'inflation pure. Il montre que moins du tiers des hausses observées lors de changements de modèles peut être attribué à l'effet qualité. Le taux d'inflation véritable serait donc proche du taux mesuré par l'indice officiel. Sur la base de la méthodologie de Bils, l'auteur conclut que l'effet qualité n'est pas une source potentielle importante de biais dans le calcul de l’indice des prix à la consommation au Canada.

Classification JEL : E31, M11, O47

Classification de la Banque : Inflation et prix; Production potentielle 


\section{Introduction}

The consumer price index (CPI) is currently the most commonly used measure of inflation in developed countries, including Canada. ${ }^{1}$ Since the introduction of inflation targeting in Canada in 1991, the CPI has been the official targeting index and is used extensively in policy debates as well as monetary policy research. ${ }^{2}$ Given the central role of the CPI in macroeconomic and monetary policy frameworks, one of the most important questions for research has been whether it correctly measures the "true" inflation in Canada.

Since the CPI measures price changes of a fixed basket of goods and services of constant quality purchased at the same store and location, prices must be adjusted to account for changes in basket composition, quality of goods and services, or store types and locations. In practice, making such adjustments is difficult and involves measurement errors. If such errors accumulate over time, the level of the CPI may be consistently different from the "true" price index. This difference is often referred to as the "measurement bias" in the CPI. ${ }^{3}$ Total bias in the CPI can be as large as measured inflation itself. For example, Beatty and Larsen (2005) estimate that, from 1978 to 2000, the CPI overstated changes in the cost of living by between 1.33 and 1.85 per cent per year.

The most important component of the total bias is imperfect measurement of the quality growth of the newly introduced consumption goods, also known as the "quality bias." 4 Quality bias is also the most difficult component to measure, particularly since, unlike other biases, it can both under- and overstate inflation. ${ }^{5}$ Estimates of the quality bias in Canada tend to be small. For example, Crawford (1998), assuming that the quality bias in the CPI comes from durable goods only, finds a quality bias of 0.14 per cent per year in the overall CPI for Canada. Likewise, by

\footnotetext{
${ }^{1}$ Alternative measures of inflation include indexes of personal consumption expenditures, the GDP deflator and unit labor cost. See Crawford, Fillion and Laflèche (1997) and Rossiter (2005) for a discussion of the advantages of using the CPI.

${ }^{2}$ Murray (2010) and Schmitt-Grohe and Uribe (2012) emphasize the importance of the correct measure of true inflation for guiding the inflation target. Boivin (2009) argues that the extent to which the true inflation is imperfectly observed has implications for the choice between inflation and price-level targeting. Another common use of the CPI is as an indicator of changes in the cost of living; e.g., for wages or pension adjustments, or for determining income tax brackets. Reis (2005) proposes a dynamic cost-of-living price index.

${ }^{3}$ Diewert (1998) and Hausman (2003) provide overviews of price measurement biases.

${ }^{4}$ In the United States, the Boskin Commission Report (1996) suggests that the Bureau of Labor Statistics overstates inflation by perhaps 1 per cent per year. Unmeasured growth in the quality of goods is put forth as the most important component, contributing an overstatement of inflation of 0.6 per cent per year, including 1.0 per cent for durables. Ruiz-Castillo et al. (2002) discuss the distributional consequences of the quality bias in the CPI.

${ }^{5}$ See Triplett $(1972,2002)$ and Hobijn (2002). According to Statistics Canada (Ducharme, 1997), there is not "enough evidence to support any precise numerical assessment of [the effect of quality bias] on the CPI."
} 
separately estimating the bias for autos, Rossiter (2005) arrives at a total quality bias in the CPI of 0.15 per cent per year, in line with Crawford (1998). ${ }^{6}$

Recent literature, however, finds that standard methods of computing the quality change may underestimate that change, and hence the quality bias. These new studies, in addition to price data, rely on consumption expenditure data at a high level of disaggregation to identify quality and pure price components of rising unit prices. In turn, this leads to more precise estimates of the quality growth and inflation. For example, Bils and Klenow (2001) use household-level consumption expenditure data to show that quality growth for 66 durable goods was understated by 60 per cent, so that pure price inflation was overstated by 2.2 per cent per year. Using CPI micro data for the United States as well as consumption expenditure data for vehicles and consumer electronics, Bils (2009) shows that two-thirds of the price increases with new models should be treated as quality growth. This implies that CPI inflation for durables has been overstated by almost 1.8 per cent per year. ${ }^{7}$

In this paper, I apply Bils' (2009) methodology to newly available CPI micro data to document the extent of quality adjustment in Canada. I first decompose the rate of unit price changes in Canada into components stemming from price changes for existing products and those for newly introduced products. I then use this breakdown to compute an upper bound on the size of quality growth (and, hence, a lower bound on price inflation) and compare it to quality adjustments implied by Statistics Canada (Statcan) methodology. Finally, using Bils' methodology, I estimate the demand (or "fashion cycle") effects, to pin down the size of quality adjustment in Canada. Comparison of my estimate to the size of quality adjustment by Statcan will then show whether there is a significant quality bias in the Canadian CPI.

I find that, according to Bils' methodology, the overall quality bias in the non-shelter Canadian CPI is close to zero, and therefore it appears not to be an important source of potential mismeasurement of CPI inflation in Canada. For durable and semi-durable goods, quality adjust-

\footnotetext{
${ }^{6}$ For autos, Rossiter uses a simple formula from Diewert (1998) that calculates the quality bias based on the share of goods in the CPI basket that have been replaced by new models, the percentage of quality (or efficiency) improvements that are missed through the linking procedures, and the measured rate of total inflation. He then takes into account the possibility of negative quality change bias arising from government-mandated safety and anti-pollution technologies that Statistics Canada treats as quality improvements.

${ }^{7}$ Most other papers that study quality adjustment by combining price and quantity data are limited to a very narrow set of goods. See, for example, Lowe (2001) and Greenlees and McClelland (2010). Greenlees and McClelland (2011) analyze the quality adjustment in the U.S. CPI data.
} 
ments made by Statistics Canada slightly overstate the extent of quality growth implied by price increases during model substitutions. For services and non-durable goods, substitutions are relatively unimportant, leaving little room for any quality bias.

The rest of this paper is organized as follows. Section 2 describes consumer price data and explains how information on unit price increases during model changeovers is used to derive an upper bound on the size of the quality change. Section 3 explains how quality adjustments are made by Statistics Canada in constructing the CPI. Section 4 uses Bils' (2009) methodology to obtain the measure of the potential quality bias in Canada. Finally, Section 5 concludes.

\section{How Do New and Better Goods Affect Unit Price Increases in Canada?}

I employ a newly available Consumer Price Research Database (CPRD) compiled by Statistics Canada from price surveys used to construct the non-shelter portion of the Canadian CPI. ${ }^{8}$ The dataset contains information about prices for goods and services posted by retail outlets across Canada from February 1998 to December 2006. Overall, the CPRD contains more than 8.6 million observations and covers about 61 per cent of the consumption basket underlying the CPI.

In the CPRD, price increases are caused by pure price inflation for existing goods, and by the entry of new goods into, and exit of old goods from, the CPI basket. ${ }^{9}$ Such changeovers of goods are conducted to keep the basket up to date with the current composition of consumption by Canadians. ${ }^{10}$ In the CPI data, new goods are introduced in two ways. First, every year around a quarter of the basket is updated to include newly available products (e.g., DVDs) and to exclude obsolete goods (e.g., videocassettes). Second, when the price of a specific model of a good is no longer available for collection, or when a newer model becomes available, the new model of the good is substituted for the old one (e.g., at the end of 2005, the 2006 Honda Civic is substituted for the

\footnotetext{
${ }^{8}$ Statcan's methods for collecting and adjusting housing prices differ substantially from those for prices posted by retail outlets for goods and services. For the purposes of this paper, we focus on non-shelter prices, contained in the CPRD. Since the CPRD is a dataset of individual prices, it also excludes goods for which prices are aggregated indexes, such as utility rates, insurance premiums, transportation fares, sport and theatre tickets, books and newspapers, entertainment CDs and DVDs, and computer equipment.

${ }^{9}$ There is also turnover of sampled products that is not related to a quality change in goods and services; e.g., when a retail outlet is permanently closed or a new outlet is introduced. I exclude such product turnover from calculations of price increases. Following Bils, I also exclude seasonal goods, such as lawn fertilizer, patio furniture, gas barbeques, seasonal clothing and footwear, hockey sticks, skates, skis, snowboards, and motorcycles. Results are insensitive to including the seasonal goods.

${ }^{10}$ Nakamura and Steinsson (2012) show that product replacement bias lowers the long-run exchange rate passthrough in the U.S. import and export price data.
} 
2005 model).

Table 1 characterizes substitutions in the CPRD. On average, substitutions occur for 3 per cent of goods in a month, or once every three years. Substitution rates are highest for durables (e.g., 7.1 per cent for vehicle purchases), semi-durables (e.g., 4.6 per cent for apparel), and fresh fruits and vegetables in non-durable goods (between 10 and 31 per cent), and they are lowest for services $(0.4$ per cent for dental care, 0.1 per cent for laundry and dry cleaning, none for telephone and driver's licence), and for such non-durables as alcohol and tobacco (0.5 per cent) and gasoline (0.5 per cent). For all goods and services, except food, a model substitution is twice as likely to be accompanied by a price change than a price quote without a substitution. For all commodities, substitution-related price changes are more likely to be increases than decreases, and with the exception of clothing and footwear, those changes are somewhat larger than price changes for the same models.

To understand how the substitution of products affects the "quality change" accounting, it is instructive to examine Figure 1, which shows a hypothetical price sequence for a good in the CPRD, say DVDs. When DVDs appear on the retail market and gain market share, Statcan introduces them into the CPI basket (the first dashed line in Figure 1). Once a particular model of a DVD good is chosen for price collection, e.g., DVD-ROM (read-only memory disk), its posted price is recorded over time (the first solid line). At some point, a new model of DVD becomes available, say, DVD-R (recordable disk), and Statcan decides to substitute the DVD-R model for the DVD-ROM to represent the price of a DVD good. Typically, new models come at a higher price, possibly reflecting their better quality (the dotted line in Figure 1). Since inflation should reflect pure price changes, the observed price change during model changeover has to be adjusted by the size of the quality change. For example, if at the time of substitution the price of the DVD-ROM (old model) was $\$ 6$ and the price of the DVD-R (new model) was $\$ 7$, only a fraction of the $\$ 1$ price difference may represent inflation. If, for example, consumers are indifferent between buying the DVD-ROM at $\$ 6$ and the DVD-R at $\$ 7$ (that is, if all of the price difference reflects the better quality of the DVD-R relative to the DVD-ROM), then the measured price inflation should be zero. The price quote line for the DVD good continues through sequences of price changes for the same models intermitted with price changes corresponding to model changeovers over time (e.g., DVD-RW substituted for DVD-R, DVD-RAM substituted for DVD-RW), until the DVD good becomes obsolete (the second dashed line in Figure 1). 
Hence, a unit price change for a good in the CPRD is the sum of price changes during basket updates (the dashed lines in Figure 1) and price changes between basket updates (i.e., for the same good). In turn, a unit price increase for the same good is the sum of price changes for the same models (solid lines) and price changes during model changeovers (dotted lines). Table 2 breaks down the unit price increase in the CPRD into its components. ${ }^{11}$

The unit price increase for durables and semi-durables is 0.5 and 0.4 per cent per year, a small portion of which is due to the entry and exit of goods. This growth in unit prices masks a combination of price decreases of 1.2 and 1.4 per cent per year for the same models, and price increases of 1.6 and 1.9 per cent per year due to forced model substitutions. Hence, for durable and semi-durable goods, model substitutions are accompanied by relatively large price increases. ${ }^{12}$ If all of the increase in unit prices during the introduction of new models or new goods represented quality change, the rate of the quality change, say, for durables, would be 1.7 per cent $(=0.1$ per cent+1.6 per cent) per year, and the rate of inflation would be -1.2 per cent per year.

In contrast to durables and semi-durables, for services and non-durable goods only a small portion of the overall increase in prices stems from substitutions. Of the 3 per cent of annual unit price increase for non-durable goods, only 0.1 per cent is due to substitutions, whereas for services the corresponding numbers are 2.7 per cent and 0.4 per cent, respectively. The smaller contribution of substitutions to price increases is due to their less frequent occurrence (services, gasoline) and less frequent price changes during a substitution (food). ${ }^{13}$

In sum, for all goods and services in the CPRD, the upper bound on quality growth, given by price increases during model substitutions, is 0.6 per cent per year. Depending on how much of this price growth is attributed to quality growth, measured inflation would fall between 1.5 and 2.1 per cent per year. According to the Statcan methodology, CPI inflation in the CPRD would

\footnotetext{
${ }^{11}$ Throughout the paper, price and quality changes are annualized and expressed in per cent per year. Aggregate log price changes are weighted means of unit log price changes. The weight for a (basic class) good category is based on consumption expenditure weights for that category. Individual price change weights are obtained by equally distributing the category weight among all price changes within that category.

${ }^{12}$ For example, for durables, the average annual unit price change during model substitutions, 1.6 per cent, is equal to the product of the fraction of substitutions (0.047), the fraction of price changes (0.554) and the average size of those changes, 5.1 per cent, multiplied by 12 . The average size of price changes is equal to the average size of price increases minus the average size of price decreases: 5.1 per cent $=0.60 \times 12.7$ per cent $-(1-0.60) \times 6.4$ per cent .

${ }^{13}$ Substitutions exhibit moderate seasonal and time-series fluctuations. For an average good in the non-shelter CPI, seasonal effects account for 21 per cent of the variance of substitution-related price changes (between 9 per cent for non-durables and 44 per cent for durables), and these price changes explain 21 per cent of the variance of unit price changes for the same good (between 11 per cent for services and 52 per cent for durables).
} 
be measured at 1.8 per cent per year. In the following sections we reassess this number using Bils' (2009) methodology.

\section{How Much of the Quality Growth is Accounted for by Statcan Methodology?}

How much of the unit price increase during product changeover is due to quality growth and how much is due to price inflation? Table 3 breaks down price increases in the CPRD into quality and inflation components. Price changes corresponding to the same model of a good are naturally treated as a measure of pure price inflation. In a similar spirit, price increases stemming from the introduction of new goods into the consumption basket are treated as representing quality change, and, hence, they do not contribute to measured inflation. Finally, price changes during model substitutions may reflect both quality and price change, and so such price changes have to be adjusted for quality change.

Statcan uses three methods to make the quality adjustment of such price increases: (i) linking, or "splicing", (ii) direct comparison, and (iii) explicit adjustments or imputations. ${ }^{14}$ The first and most common method implies that the difference in price between the new product and the old one represents the effect of a change in quality. This method is predominantly used for health care products, wine, processed food and furniture. The second method consists of finding the most comparable replacement for a product that has disappeared from the shelves. In this case, the difference in prices is normally considered to be a pure price change. This method is employed for unprocessed food, gasoline and cigarettes. Finally, the last method implies explicit adjustments to correct for quality changes, using hedonic regressions (e.g., for computers), ${ }^{15}$ prices of new components of a good (cars), or, if no information is available to allow explicit adjustments, prices for other goods in the same category (durables). Splicing and direct comparison methods are each used for about 45 per cent of all substitutions, with the remaining 10 per cent of quality adjustments made via explicit adjustment or imputation.

Table 3 summarizes Statcan's treatment of unit price increases, for durables (top panel) and all non-shelter goods and services (bottom panel). According to my calculations, out of 1.6 and 1.9

\footnotetext{
${ }^{14}$ The International Labour Office (2004) describes quality adjustment in the Canadian CPI. Similar quality adjustment methods are used in most developed countries (Ducharme 1997).

${ }^{15}$ See $\mathrm{Yu}$ and Prud'homme (2010) for a discussion of practical issues facing practitioners of hedonic studies, using price data for Internet service providers in Canada from 1993 to 2000.
} 
per cent of price increases during substitutions for durables and semi-durables, 0.6 and 0.7 per cent, respectively, or about one-third, are attributed to quality growth, while the remaining 1.0 and 1.2 per cent are reported as price inflation. As I already noted, for services and non-durables substitutionrelated price increases are small, 0.4 and 0.1 per cent per year. Altogether, for all non-shelter goods and services, out of 0.6 per cent of substitution-related price increases, 0.3 per cent are attributed by Statcan to quality growth, and the remaining 0.3 per cent to inflation. Hence, according to Statcan, around half of price increases during model changeovers reflect inflation. This degree of quality adjustment is substantial: e.g., according to Bils, only one-seventh of substitution-related price increases for durables in the United States is attributed to quality growth, an adjustment at least three times smaller than I find for Canada.

Table 4 compares quality growth measured by Statcan to the upper bound on the quality growth given by the difference between the rate of the overall unit price increase and that for samemodel prices. For both durable and semi-durable goods, quality grew by 0.7 per cent per year, which is almost three times smaller than the 1.7 and 1.9 per cent growth, respectively, of the upper bound on quality. If all model-changeover price increases represented quality growth, measured inflation for durables and semi-durables, cumulated over the entire nine-year CPRD sample period, would be overstated by 9 and 10 percentage points, respectively. For services and non-durable goods, the upper bound on potential quality bias over nine years is much smaller, 0.8 and 0.3 percentage points. Overall, for all non-shelter goods and services, the upper bound on potential quality bias is rather small, almost 3 per cent over nine years, or only 0.3 per cent per year.

\section{Quantifying Quality Bias}

\subsection{Upper bound on quality growth}

How much of the price increase during forced substitutions indeed reflects quality growth? To answer this question, Bils (2009) notes that if higher prices of new models represented price inflation, consumers would substitute away from those relatively expensive models toward old but cheaper ones. Using data on quantities for vehicles and consumer electronics, Bils tests the hypothesis that higher prices of new models represent price inflation. He rejects this hypothesis by showing that substitutions in fact do not reduce market share. 
To test the same hypothesis using Canadian data, I use the data on monthly unit sales by car model from WardsAuto.com for Canada from February 1998 through December 2006. I merge these data with monthly substitution rates for car models from the CPRD for the same period. I use the obtained panel to estimate the response of unit price inflation, CPI price inflation and the change in market shares for car sales to substitution rates for car models. Table 5 provides the estimated coefficients. Since substitutions predominantly take place at the end of the year, typically in November, most car model-month observations correspond to zero substitution rates. The table therefore reports the results separately, including and excluding those observations.

The estimated regression coefficients represent per cent differences in dependent variables between car models that experienced 100 per cent substitution rates and those with no substitutions. The total number of observations used in the regression, including those with zero substitution rates, is 2,265. Substitutions are associated with 32.7 per cent greater unit price increases, only a small portion of which, 1.7 per cent, is attributed to price inflation, and the remaining 31.0 per cent to quality growth. When model-months with zero substitution rates are excluded, 1.4 per cent out of 29.7 per cent is captured as price inflation, and 28.3 per cent as quality increase. These results are consistent with my findings that the degree of quality adjustment by Statcan is large (see Table 3).

The third row in Table 5 shows that there is no evidence that car models with higher substitution rates lose market share. The estimated coefficient is positive and not statistically significant from zero. Hence, if the identifying assumption is correct, and model changeovers are unrelated to consumer demand for those models, the fact that, despite higher relative prices, consumers shift their expenditures toward newer models implies that those higher prices imply quality growth. That is, price changes during forced substitutions (reported in Table 3) should entirely be attributed to quality growth: 1.7 and 1.9 per cent per year for durables and semi-durables, 0.4 and 0.1 per cent per year for services and non-durables, and 0.6 per cent per year for all non-shelter goods and services (see Table 4$) \cdot{ }^{16}$

As Bils notes, the key identifying assumption may not always be true; i.e., higher prices of new models of the same good may represent higher demand for those models for reasons that are not related to their quality. Therefore, price changes during model substitutions represent an upper

\footnotetext{
${ }^{16}$ Note that, in this case, price changes during model changeovers pin down the size of the quality change, so that one does not need to know demand elasticities to determine the quality shift.
} 
bound on the size of quality growth. In the next subsection, I provide a point estimate for the demand component in unit price changes during model changeovers.

\subsection{Accounting for the demand component in unit price increases}

Consider an example of a "fashion cycle" for novels. When a new novel comes out, people may have a preference for reading it right away, because they do not want to hear about it from someone who already read it. In this case, the demand for new novels will be higher (than for older ones), which leads to their relatively high price regardless of their quality. Assuming that, in contrast to quality effects, such fashion cycles are temporary, Bils measures the importance of those effects by measuring the persistence of relative prices during model substitutions, and how this persistence depends on the share of the price increase attributed by Statcan to quality growth.

One can obtain a point estimate of the quality growth during model changeovers by multiplying the unit price increase during substitutions by the share of the quality component of the price increase (Table 6). Bils finds that fashion cycles account for one-third of the price differences for durables and at least three-quarters for apparel, which means that the quality component of the unit price increases during forced substitutions is two-thirds for durables and one-quarter for apparel. This estimate of the quality component for durables is almost five times higher than the quality component implied by the U.S. Bureau of Labor Statistics (BLS) quality adjustment methods, implying, according to Bils, a substantial quality bias in durables in the United States.

I first apply Bils' estimate of the quality component in BLS data directly to the CPRD; i.e., I multiply the size of the price change during substitutions (row 1) by the share of quality growth during substitutions estimated by Bils (row 2). In this case, quality growth during substitutions boils down to 1.0 and 0.5 per cent per year for durables and semi-durables (row 3). ${ }^{17}$ Taking into account that the quality component for services and non-durable goods in Bils is zero, the overall estimate of quality growth is 0.25 per cent per year. This estimate is very close to 0.28 per cent quality growth implied by Statcan quality adjustment methods (row 6), yielding a small negative quality bias of -0.03 per cent per year (row 8).

\footnotetext{
${ }^{17}$ Since clothing and footwear account for most of the weight in the semi-durable goods in the CPRD, I apply Bils' point estimate of the quality component for apparel to all semi-durable goods. Since Bils excludes services and non-durable goods from his analysis, I assume that his point estimate of the quality component for those commodities is zero.
} 
I then repeat Bils' estimation of the quality component in substitution-related price increases using the CPRD. The estimated quality component in the CPRD is 0.32 for durables and 0.16 for semi-durables (row 4), which is twice as small as 0.64 and 0.25 found by Bils using U.S. CPI data, and also smaller than 0.40 and 0.38 implied by Statcan quality adjustments. Hence, while for the United States CPI quality growth during model changeovers might have been underestimated, for Canada it may have been overestimated. This is not surprising, since the share of substitutionrelated price increases attributed to quality by official methods is at least three times higher in the CPRD than the share reported by Bils in the BLS data. Furthermore, in the CPRD, price increases during model changeovers persist less than price increases for matched models, suggesting that some quality adjustments may have included more transient pure price movements. Overall quality growth using the quality component estimated for the CPRD amounts to 0.16 per cent per year (row 5), which is less than 0.28 per cent per year implied by official methods, leading again to a negative quality bias of -0.12 per cent per year (row 9).

These results, stemming from information on quality adjustments at a commodity level, allow me to qualify assumptions made in earlier work by Crawford (1998) and Rossiter (2005): namely, that most of the quality bias occurs in durable goods, whereas it averages to zero for the remaining goods and services. Under these assumptions, quality bias in non-shelter CPI would amount to 0.20 per cent per year, or 0.14 per cent for the overall CPI - both numbers consistent with Crawford (1998) and Rossiter (2005). ${ }^{18}$ I find that, first, not all price increases during substitutions for durables represent quality growth: even for Bils' optimistic estimate of the quality component for durables, the bias in durables would decrease from 0.98 to 0.39 per cent per year. Second, the quality bias is negative for goods other than durables: the average bias for non-durables, semi-durables and services is -0.14 (using Bils' quality component) and -0.12 (using the estimated component). The combination of lower unaccounted quality growth for durables and negative quality bias for the remaining goods leads to a small and negative total quality bias in the CPRD.

Finally, the last two columns of Table 6 provide the results for alternative restrictions on the CPRD sample. Including seasonal items (about 2 per cent of the observations), as expected,

\footnotetext{
${ }^{18}$ For durables, the portion of price increases during substitutions not accounted by official methods is 0.98 per cent per year (=1.62-0.64, see Table 6$)$. Multiply this by the relative weight of durables in the CPRD, 0.20 , or in overall CPI, 0.14, to obtain the quality bias implied by assumptions in Crawford and Rossiter.
} 
raises the unit price increases during substitutions from 0.63 to 0.88 per cent per year. The implied quality bias is 0.04 using Bils' estimate of the quality component, and -0.08 using the CPRD estimate. Secondly, I exclude from the original sample substitutions that coincide or immediately follow price discounts. Large price discounts may lead to faster sales of the old models and the ensuing substitution of the new ones, e.g., during clearance sales in clothing and footwear. Price increases during such substitutions, if not appropriately accounted for, will contribute toward higher measured quality growth. For semi-durables, when sale-related substitutions are excluded from the sample, unit price growth during substitutions falls from 1.86 to 0.95 . Corresponding quality growth implied by Statcan methods also falls, from 0.71 to 0.46. Using Bils' estimate of the quality component, 0.25 , the implied bias in semi-durables changes from -0.24 to -0.22 , and the overall bias changes from -0.03 to -0.04 . Hence, the estimated bias is not significantly affected by excluding sale-related substitutions, suggesting that Statcan's quality adjustment for such substitutions is consistent with substitutions not related to price discounts.

\section{Conclusions}

Using Bils' methodology, I find that the overall quality bias in the non-shelter Canadian CPI is close to zero. For durable and semi-durable goods, quality adjustments made by Statistics Canada slightly overstate the extent of quality growth implied by price increases during model substitutions. For services and non-durable goods, substitutions are relatively unimportant, leaving little room for any quality bias. I conclude that the quality bias is not an important source of potential mismeasurement of CPI inflation in Canada. 


\section{References}

[1] Beatty, T. and E. Larsen. 2005. "Using Engel Curves to Estimate Bias in the Canadian CPI as a Cost of Living Index," Canadian Journal of Economics 38(2): May 2005, 482-499.

[2] Bils, M. 2009. "Do Higher Prices For New Goods Reflect Quality Growth or Inflation?" Quarterly Journal of Economics 124(2): May 2009, 637-675.

[3] Bils, M. and P. Klenow. 2001. "Quantifying Quality Growth," American Economic Review 91: 1006-1030.

[4] Boivin, J. 2009. "Getting it Right When You Might Be Wrong: The Choice Between Price Level and Inflation Targeting," C.D. Howe Institute Commentary.

[5] Boskin Commission Report. 1996. Toward a More Accurate Measure of the Cost of Living, Final Report to the Senate Finance Committee from the Advisory Commission to Study the Consumer Price Index, 1996. Available online at http://www.ssa.gov/history/reports/boskinrpt.html.

[6] Crawford, A. 1998. "Measurement Biases in the Canadian CPI: An Update." Bank of Canada Review (Spring): 38-56.

[7] Crawford, A., J.-F. Fillion, and T. Laflèche. 1997. "Is the CPI a Suitable Measure for Defining Price Stability?" In Price Stability, Inflation Targets, and Monetary Policy, 39-73. Proceedings of a conference held by the Bank of Canada, May 1997. Ottawa: Bank of Canada.

[8] Diewert, W.E. 1998. "Index Number Issues in the Consumer Price Index." Journal of Economic Perspectives 12(1): 47-58.

[9] Ducharme, L.M. 1997. "The Canadian Consumer Price Index and the Bias Issue: Present and Future Outlooks," in Bias in the CPI: Experiences From Five OECD Countries, edited by L. M. Ducharme, Catalogue No. 62F0014MPB, No. 10, Prices Division, Statistics Canada.

[10] Greenlees, J. and R. McClelland. 2010. "Superlative and regression-based consumer price indexes for apparel using U.S. scanner data," Manuscript, U.S. Bureau of Labor Statistics.

[11] Greenlees, J. and R. McClelland. 2011. "Does Quality Adjustment Matter for Technologically Stable Products? An Application to the CPI for Food," Bureau of Labor Statistics Working Paper No. 444. 
[12] Hausman, J. 2003. "Sources of Bias and Solutions to Bias in the Consumer Price Index," Journal of Economic Perspectives 17(1): 23-44.

[13] Hobijn, B. 2002. "On both sides of the quality bias in price indexes," Staff Reports No. 157, Federal Reserve Bank of New York.

[14] International Labour Office. 2004. "Consumer Price Index Manual: Theory and Practice." Geneva.

[15] Lowe, R. 2001. "Televisions: Quality Changes and Scanner Data," Catalogue No. 62F0014MIB, Series No. 14, Prices Division, Statistics Canada.

[16] Murray, J. 2010. "Re-examining Canada's Monetary Policy Framework: Recent Research and Outstanding Issues." Remarks for the Canadian Association for Business Economics, Kingston, ON, 24 August 2010.

[17] Nakamura, E. and J. Steinsson. 2012. "Lost in Transit: Product Replacement Bias and Pricing to Market," American Economic Review, 102(7): 3277-3316.

[18] Reis, R. 2005. "A cost-of-living dynamic price index, with an application to indexing retirement accounts," CEPR Discussion Papers No. 5394.

[19] Rossiter, J. 2005. "Measurement Bias in the Canadian Consumer Price Index," Bank of Canada Working Paper No. 2005-39.

[20] Ruiz-Castillo, J., E. Ley, and M. Izquierdo. 2002. "Distributional aspects of the quality change bias in the CPI: evidence from Spain," Economics Letters, 76(1): 137-144.

[21] Schmitt-Grohe, S. and M. Uribe. 2012. "On Quality Bias and Inflation Targets," Journal of Monetary Economics, 59: 393-400.

[22] Triplett, J. 1972. "Quality Bias in Price Indexes and New Methods of Quality Measurement," in Price Indexes and Quality Change: Studies in New Methods of Measurement, Zvi Grilliches (ed.), Cambridge, MA: Harvard University Press. 
[23] Triplett, J. 2002. "Quality Adjustments in Conventional Price Index Methodologies," Handbook on Quality Adjustment of Price Indexes for Information and Communication Technology Products, OECD: Paris.

[24] Yu, K. and M. Prud'homme. 2010. "Econometric issues in hedonic price indices: the case of Internet service providers," Applied Economics 42(15): 1973-1994. 
Table 1. Substitutions in Statcan data

\begin{tabular}{lccccc}
\hline \hline & $\begin{array}{c}\text { Durable } \\
\text { goods }\end{array}$ & $\begin{array}{c}\text { Non-durable } \\
\text { goods }\end{array}$ & Services & $\begin{array}{c}\text { Semi-durable } \\
\text { goods }\end{array}$ & All \\
\hline \hline CPI weight, \% & 12.0 & 24.5 & 16.8 & 5.6 & $\mathbf{5 8 . 9}$ \\
Fraction of substitutions & 4.7 & 3.3 & 1.1 & 5.1 & $\mathbf{3 . 3}$ \\
Frequency of price changes & 25.4 & 38.8 & 7.0 & 21.3 & $\mathbf{2 5 . 3}$ \\
$\quad$ no subs & 24.9 & 38.6 & 6.9 & 20.1 & $\mathbf{2 5 . 0}$ \\
$\quad$ subs & 55.4 & 33.5 & 26.9 & 42.3 & $\mathbf{3 7 . 4}$ \\
Absolute size of price changes & 9.7 & 14.6 & 8.5 & 27.8 & $\mathbf{1 3 . 1}$ \\
$\quad$ no subs & 9.6 & 14.5 & 8.6 & 28.9 & $\mathbf{1 3 . 2}$ \\
$\quad$ subs & 10.2 & 17.3 & 8.9 & 19.4 & $\mathbf{1 3 . 9}$ \\
Fraction of price increases in price changes & 52.2 & 55.7 & 74.1 & 50.5 & $\mathbf{5 6 . 0}$ \\
$\quad$ no subs & 51.6 & 55.7 & 74.0 & 49.0 & $\mathbf{5 5 . 8}$ \\
$\quad$ subs & 60.1 & 62.5 & 79.9 & 62.0 & $\mathbf{6 4 . 8}$ \\
\hline \hline
\end{tabular}

Notes: Data from Statistics Canada Consumer Price Research Database (CPRD) for non-shelter goods and services from February 1998 to December 2006. Seasonal goods are excluded. Fractions and absolute sizes of price changes are in percentage points, at monthly frequency. 
Table 2. Annual Price Inflation and Quality Growth

\begin{tabular}{|c|c|c|c|c|c|}
\hline & $\begin{array}{l}\text { Durable } \\
\text { goods }\end{array}$ & $\begin{array}{l}\text { Non-durable } \\
\text { goods }\end{array}$ & Services & $\begin{array}{l}\text { Semi-durable } \\
\text { goods }\end{array}$ & All \\
\hline CPI weight, \% & 12.0 & 24.5 & 16.8 & 5.6 & 58.9 \\
\hline Number of obs, x 1000 & 451 & 5059 & 586 & 496 & 6592 \\
\hline$\pi$ unit price & 0.5 & 3.0 & 2.7 & 0.4 & 2.1 \\
\hline$=\pi$ new goods & 0.1 & 0.0 & 0.0 & 0.0 & 0.0 \\
\hline$+\pi$ same good & 0.4 & 3.0 & 2.7 & 0.4 & 2.1 \\
\hline$=\pi$ same model & -1.2 & 2.9 & 2.3 & -1.4 & 1.5 \\
\hline$+\pi$ new models & 1.6 & 0.1 & 0.4 & 1.9 & 0.6 \\
\hline \multicolumn{6}{|l|}{ Upper bound on quality } \\
\hline$=\pi$ new goods $+\pi$ new models & 1.7 & 0.1 & 0.4 & 1.9 & 0.6 \\
\hline \multicolumn{6}{|l|}{ Lower bound on inflation } \\
\hline$=\pi_{\text {same model }}$ & -1.2 & 2.9 & 2.3 & -1.4 & 1.5 \\
\hline
\end{tabular}

Notes: Data from Statistics Canada Consumer Price Research Database (CPRD) for non-shelter goods and services from February 1998 to December 2006. Seasonal goods are excluded. All price changes are annualized, in \% per year. $\pi_{\text {unit price }}{ }^{-}$ unit price for all goods, $\pi_{\text {new goods }}$ - unit price for new goods, $\pi_{\text {same good }}$ - unit price for new goods, $\pi_{\text {same model }}$ - unit price for new goods, $\pi_{\text {new models }}$ - unit price for new models. 
Table 3. Statcan Treatment of Price Increases with Forced Substitutions

\begin{tabular}{|c|c|c|c|c|}
\hline & $\begin{array}{c}\text { Per cent of } \\
\text { quotes } \\
\text { (unweighted) }\end{array}$ & $\begin{array}{l}\text { Unit price } \\
\text { change }\end{array}$ & $\begin{array}{l}\text { Inflation } \\
\text { (Statcan } \\
\text { methods) }\end{array}$ & $\begin{array}{l}\text { Quality } \\
\text { growth } \\
\text { (Statcan } \\
\text { methods) }\end{array}$ \\
\hline \multicolumn{5}{|c|}{ Durable goods } \\
\hline All quotes (\%) & 100 & 0.5 & -0.2 & 0.7 \\
\hline No substitution (same model) & 95.3 & -1.2 & -1.2 & 0 \\
\hline Substitution (new models) & 4.7 & 1.6 & 1.0 & 0.6 \\
\hline Basket updates (new goods) & 0.0 & 0.1 & 0 & 0.1 \\
\hline \multicolumn{5}{|c|}{ All non-shelter goods and services } \\
\hline All quotes (\%) & 100 & 2.1 & 1.8 & 0.3 \\
\hline No substitution (same model) & 96.7 & 1.5 & 1.5 & 0 \\
\hline Substitution (new models) & 3.3 & 0.6 & 0.3 & 0.3 \\
\hline Basket updates (new goods) & 0.0 & 0.0 & 0 & 0.0 \\
\hline
\end{tabular}

Notes: Data from Statistics Canada Consumer Price Research Database (CPRD) for non-shelter goods and services from February 1998 to December 2006. Seasonal goods are excluded. All price changes are annualized, in \% per year. 


\section{Table 4. Annual Quality Growth}

Quality growth

\begin{tabular}{|c|c|c|}
\hline $\begin{array}{l}\text { Dura } \\
\text { good }\end{array}$ & $\begin{array}{l}\text { Non- } \\
\text { durable } \\
\text { goods }\end{array}$ & Se \\
\hline
\end{tabular}

1.7
0.0

0.1
0.3

0.4

1.7

0.7

0.7

0.3

$\vec{\infty}$

Notes: Data from Statistics Canada Consumer Price Research Database (CPRD) for non-shelter goods and services from February 1998 to December 2006. Seasonal goods are excluded. All price changes are annualized, in $\%$ per year. 


\section{Table 5. Response of Unit Price Inflation, CPI Price Inflation and Market Share of Unit Sales to Substitution Rate for Cars}

\begin{tabular}{lcc}
\hline \hline Dependent variable & $\begin{array}{c}\text { Including } \\
\text { months with } \\
\text { no subs }\end{array}$ & $\begin{array}{c}\text { Excluding } \\
\text { months with } \\
\text { no subs }\end{array}$ \\
\hline \hline & 32.7 & 29.7 \\
$\Delta \ln$ (unit price) & $(0.3)$ & $(1.4)$ \\
$\Delta \ln ($ CPI price) & 1.7 & 1.4 \\
& $(0.3)$ & $(1.2)$ \\
$\Delta \ln$ (market share of sales) & $\mathbf{0 . 1}$ & $\mathbf{4 . 5}$ \\
Number of model-month obs & $\mathbf{( 5 0 . 0 )}$ & $\mathbf{( 7 . 3 )}$ \\
\hline \hline
\end{tabular}

Notes: Independent variable is the monthly rate of forced substitutions for that vehicle model. Data from Statistics Canada Consumer Price Research Database (CPRD) for non-shelter goods and services, and WardsAuto.com, both from February 1998 to December 2006. Standard errors are in parentheses. Regressions include monthly time-period dummies. 
Table 6. Annual Quality Growth from Substitutions

\begin{tabular}{llccccccc}
\hline \hline & Quality growth measured by & $\begin{array}{c}\text { Durable } \\
\text { goods }\end{array}$ & $\begin{array}{c}\text { Non- } \\
\text { durable } \\
\text { goods }\end{array}$ & Services & $\begin{array}{c}\text { Semi- } \\
\text { durable } \\
\text { goods }\end{array}$ & All & $\begin{array}{c}\text { All } \\
\text { (including } \\
\text { seasonal) }\end{array}$ & $\begin{array}{c}\text { All (excluding } \\
\text { sale-related } \\
\text { subs) }\end{array}$ \\
\hline \hline 1 & Price change during substitutions & 1.62 & 0.06 & 0.36 & 1.86 & $\mathbf{0 . 6 3}$ & 0.88 & 0.70 \\
2 & quality component (Bils 2009) & 0.64 & 0.00 & 0.00 & 0.25 & & 0.00 & 0.00 \\
3 & quality growth (Bils 2009) & 1.04 & 0.00 & 0.00 & 0.46 & $\mathbf{0 . 2 5}$ & 0.32 & 0.27 \\
4 & quality component (CPRD) & 0.32 & 0.22 & 0.22 & 0.16 & & 0.00 & 0.00 \\
5 & quality growth (CPRD) & 0.53 & 0.01 & 0.08 & 0.30 & $\mathbf{0 . 1 6}$ & 0.21 & 0.19 \\
$\mathbf{6}$ & Quality growth (Statcan methods) & 0.64 & 0.03 & 0.27 & 0.71 & $\mathbf{0 . 2 8}$ & 0.29 & 0.31 \\
7 & Quality bias & & & & & & & -0.04 \\
8 & Bils' (2009) quality component & 0.39 & -0.03 & -0.27 & -0.24 & $\mathbf{- 0 . 0 3}$ & 0.04 & -0.04 \\
9 & CPRD quality component & -0.12 & -0.01 & -0.19 & -0.41 & $\mathbf{- 0 . 1 2}$ & -0.08 & -0.12 \\
\hline \hline
\end{tabular}

Notes: Data from Statistics Canada Consumer Price Research Database (CPRD) for non-shelter goods and services from February 1998 to December 2006. For all columns except the last two, seasonal goods are excluded. For the last column, substitutions that coincide with a sale in the current or previous month are excluded. All price and quality changes are annualized, in \% per year. Quality component is the fraction of price change during a substitution attributed to quality growth. Quality component is taken from Bils (2009) directly, and is estimated for the CPRD using regressions from Bils (2009). 
Figure 1. Hypothetical Across-Time Price Sequence for a Given Good
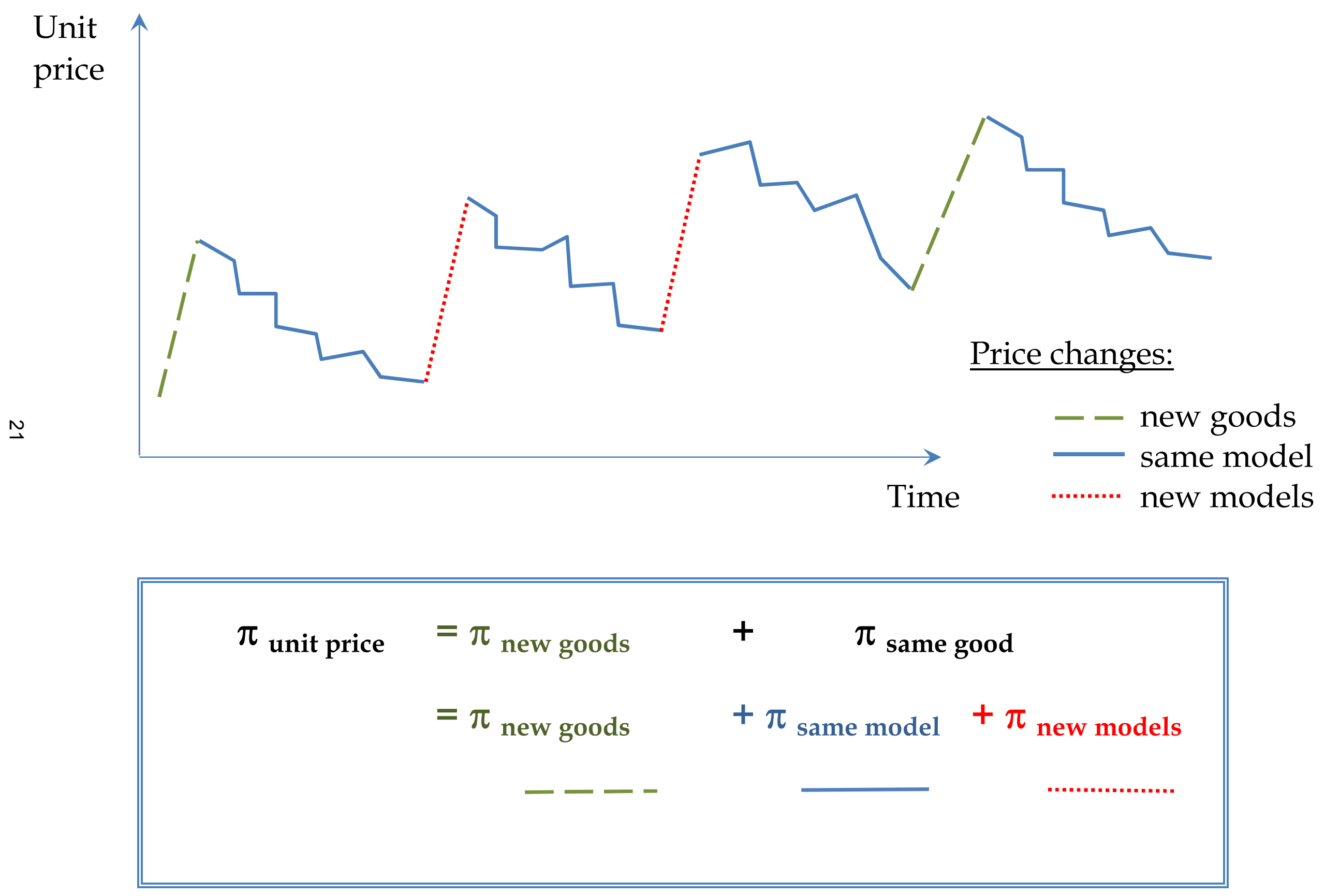